\title{
Quality of Life of Dentists in Riyadh City, Kingdom of Saudi Arabia
}

\author{
Mossad O. Al-Mehrej ${ }^{1}$, Navin Anand Ingle ${ }^{2}$, Mansour K. Assery ${ }^{3}$, Abdullah Alsirhani ${ }^{4}$ \\ 1,2 Department of Dental Public Health, College of Dentistry, Riyadh Elm University, Riyadh, Kingdom of Saudi Arabia. \\ ${ }^{3}$ Department of Prosthodontics, Vice Rector Riyadh Elm University, Riyadh, Kingdom of Saudi Arabia. ${ }^{4}$ Prince Sultan \\ Military Medical City, Riyadh Colleges of Dentistry, Pharmacy - RCsDP, Riyadh, Kingdom of Saudi Arabia.
}

\section{ABSTRACT}

\section{BACKGROUND}

Life of a health care professional revolves around many influencing factors. Health care professional quality of life is of utmost importance; because they are the individuals who bring changes in the health care and society.

\section{METHODS}

This cross-sectional survey used World Health Organization (WHO) QOL-BREF questionnaire which assesses QOL in physical, psychological, social, and environmental domains which was distributed to general dental practitioners, specialists, and consultants, working in both public and private sectors. The completed questionnaires were coded and analysed using the SPSS IBM software version 23.

\section{RESULTS}

Males had better QOL in physical health, psychological, and social relationships domains of the WHOQOL-BREF. Married dentists had better QOL than singles on the physical health, psychological, and environmental domains. QOL of consultants was better than specialists and general practitioners on all domains. Furthermore, consultants reported statistically significantly better QOL on the physical health, psychological, and social relationships domains.

\section{CONCLUSIONS}

Most of the participating dentists felt that they had good quality of life irrespective of gender and work grades.
Corresponding Author:

Mossad o. al-Mehrej.

Department of Dental Public Health, College of Dentistry, Riyadh Elm University, Riyadh, Kingdom of Saudi Arabia.

E-mail:

mossad.o1.almehrej@student.riyadh.edu.sa

DOI: $10.14260 / \mathrm{jemds} / 2020 / 772$

How to Cite This Article:

Al-Mehrej MO, Ingle NA, Assery MK, et al. Quality of life of dentists in Riyadh city, Kingdom of Saudi Arabia. J Evolution Med Dent Sci 2020;9(47):3517-3522, DOI: 10.14260/jemds/2020/772

Submission 29-06-2020,

Peer Review 06-10-2020,

Acceptance 12-10-2020,

Published 23-11-2020.

Copyright (C) 2020 Mossad O. Al-Mehrej et al. This is an open access article distributed under Creative Commons Attribution License [Attribution 4.0 International (CC BY 4.0)]

\section{KEY WORDS}

Dentists, Quality of Life, WHOQOL-BREF 


\section{BACKGROUND}

Dental health care professionals include general dental practitioners, specialist in various dental specialties, dental hygienists, and dental surgery assistants. Dental technicians though they are an important part of the dental team, do not have direct exposure to the patient work, unless they have been called for, in special cases. ${ }^{1,2}$

As with any other health care professionals, general dental practitioners and specialist in various dental specialty practices and their wellbeing is often related to their Quality of Life (QOL). Many factors are influencing their wellbeing or QOL. ${ }^{2}$ The area they practice, the income generated from the dental practice, their communication with the fellow dentists or specialist, their social life, marital status, etc. are some of the known factors. Though the field of dental specialty appears to be attractive and lucrative, several hurdles are expected to be passed after graduating and starting dental practice. ${ }^{3}$

The pace at dentistry is moving more towards digital dentistry, one has to be constantly updating the skills and knowledge about the newer aspects to fulfil the needs of the patient and at par with the fellow practitioners. ${ }^{4}$ As an academician cum clinician, dentist needs to fulfil the responsibility of entrepreneur too. As more links are getting established between the oral disease and systemic disease, there is further demand on the dentist to imbibe the skill of managing the "oral physician" role too. Overall there are more avenues to fall towards the stress, which in turn may be responsible for the QOL. ${ }^{5}$ The term QOL has varied concepts around the globe. ${ }^{1}$ World Health Organization (WHO) defines QOL as an individual's perception of their position in life in the context of the culture and value systems in which they live and in relation to their goals, expectations, standards, and concerns. Further, QOL refers to a subjective evaluation embedded in a cultural, social, and environmental context. ${ }^{3}$ Though the concept of QOL was first introduced in economics, gradually it is been used in medicine and dentistry. ${ }^{5}$

Is the QOL worth discussing with the dental health care professional? Answer is certainly yes. With the number of dentists passing out each year and the job concerns, assessment of QOL is considered to be appropriate. As it was discussed in many cross-sectional studies the dentists are being subjected to both physical and psychological stress. Physical well-being is impacted by the need to be fit, to sit for a considerable time in ergonomically right position. Failure to do will invite the disorder related to neck and hands. Addition to this, some of the factors affecting dentists' mental well-being were time, scheduling demands, negative patient perceptions, income related issues, conflicts between profits and professional ethics, repetitive nature of the job, uncooperative patients, long working hours, and unsatisfactory staff and auxiliary support.6,7

\section{Objectives}

- To evaluate the QOL of dentists in Riyadh city, Kingdom of Saudi Arabia.

- To compare QOL of male and female dentist.

- To compare QOL of dentist working in public and private sectors.
- To assess the socio-demographic factor related to the QOL of dentists.

\section{Expected Outcome}

- The study results can be utilized by the Ministry of Health for decision making to improve the quality of health among the dental health care professionals.

- Dental organization / statutory bodies can take necessary measures to improve or maintain the QOL among dentists.

- The dental professionals can utilize this to improve their QOL based on the outcome.

\section{METHODS}

A cross-sectional study was carried out in Riyadh city, KSA. The questionnaire was distributed to random sample of 101 dentists. The dentists willing to participate in the study were requested to fill out the questionnaire in an electronic format through an online link, according to what they felt during the last 2 weeks. The forms initially were provided to 125 dental professionals, out of 101 respondents were taken for the final survey, making it a response rate of $81 \%$. Total enumeration sampling technique was employed, wherein all the dental care professionals of the institution were included for the sample. The study obtained the approval by the Ethics Committee at the College of Dentistry, Riyadh Elm University, registration number FPGRP / 2019 / 422 / 19, IRB approval number "FPGRP / 2019 / 422 / 19 / 24". The dentists were informed about the aim and objectives of the study and their written informed consent were obtained. Anonymity and confidentiality were assured.

\section{Instrument, Measures, and Data Collection}

To evaluate the QOL of dentists, a WHO QOL Assessment-BREF (WHOQOL-BREF) questionnaire was used. The questionnaire addresses four domains of QOL which are physical, physiological, social relationships, and environmental. Physical domain includes pain and discomfort facet. Physiological domain examines how often a person experiences positive and negative perceptions and what impact they have on a person's daily functioning. Social domain addresses the personal relationships and social support a person has and their impact on his / her life. Environmental domain includes physical safety facet which examines if a person feels secure from any physical harms.

The WHOQOL-BREF questionnaire is a valid instrument and it demonstrates good internal consistency. ${ }^{8}$ Minor modifications were done in the questionnaire to suit the local culture. Computed scores for each domain were calculated ranging from 0 to 100 . The scoring of the domains was done in a positive direction. The mean scores of items within each domain were used to calculate the whole domain score. The sum was multiplied by 4 to make the score of the domain compatible with the WHOQOL-100 score. The sum of all the domains was then converted into $0-100$ scale using the formula as mentioned below. 
- Physical domain - [(6 - Q3) + (6 - Q4) + Q10 + Ql5 + Ql6 + Q17 + Q18] x 4

- Psychological domain - $(\mathrm{Q} 5+\mathrm{Q} 6+\mathrm{Q} 7+\mathrm{Q} 11+\mathrm{Q} 19+(6-$ Q25)) $x 4$

- Social relationships domain - $(\mathrm{Q} 20+\mathrm{Q} 21) \times 4$

- $\quad$ Environment domain - $(\mathrm{Q} 8+\mathrm{Q} 9+\mathrm{Ql} 2+\mathrm{Ql3}+\mathrm{Q} 14+\mathrm{Q} 22$ + Q23 + Q24) $\times 4$

- Transformed score - (SCORE - 4) x (100 / 16)

\section{Statistical Analysis}

Data was analysed using SPSS IBM version 23 (IBM SPSS Statistics for Windows, Version 21.0, and IBM Corp: Armonk, NY). Descriptive statistics was performed, and frequencies, means, and standard deviations were reported. Stepwise multiple linear regression analysis was performed to assess the relationship between each of the domains and the independent variables. A $p$ value of $\leq 0.05$ was considered statistically significant.

\section{RESULTS}

\section{Demographic Characteristics}

Among the 101 respondents, over half were male $(55.4 \%, \mathrm{n}=$ 56), $58.0 \%(n=58)$ of them were working in public jobs, more than half of them were general dentists $(58.4 \%, \mathrm{n}=59)$, and $54.5 \%(n=55)$ obtained basic dental qualification (BDS or equivalent) from private dental college. Respondents' year of graduation from dental school ranged from 1983 - 2019. Approximately one quarter of the respondent's average monthly income is less than 10,000 SR $(24.8 \%, n=25)$. The majority of the respondents were married $(60.4 \%, \mathrm{n}=61)$ and are currently not ill $(78.0 \%, \mathrm{n}=78)$ (Table 1$)$. The Mean \pm SD age of the respondents was $32.6 \pm 6.0$ years, ranging from 24 53 years.

\section{Quality of Life}

About $22.8 \%(n=23)$ respondents expressed their quality of life is very good, followed by slightly above half of the respondents felt as good $(50.1 \%, \mathrm{n}=51)$. Subjects responded as poor and very poor were very low and $19.8 \%$ responded their life neither as good nor poor (Figure 1).

\section{Satisfaction with the Health}

Most of the respondents reported that they were satisfied $(40.6 \%, n=41)$ and very satisfied with their health $(22.8 \%, n$ $=23$ ). However, it is also noted that about $15.8 \%$ respondents reported to be dissatisfied with their health and $3.0 \%$ very dissatisfied (Figure 2).

\section{Quality of Life Domains (WHOQOL - 100) in Dentists}

WHOQOL - 100, mean transformed score assessed on a scale of 0 - 100 revealed the following result as depicted in Table 2 . It was observed that, highest mean \pm standard deviation score was seen for social relationship domain $(59.68 \pm 29.69)$ and the least score was for environment domain $(54.09 \pm 17.94)$.

\begin{tabular}{|c|c|c|c|}
\hline & & Frequency (n) & $\%$ \\
\hline \multirow{2}{*}{ Gender } & Male & 56 & 55.4 \\
\hline & Female & 45 & 44.6 \\
\hline \multirow{4}{*}{ Type of Job } & Private & 30 & 30.0 \\
\hline & Public & 58 & 58.0 \\
\hline & Both & 12 & 12.0 \\
\hline & General Dentist & 59 & 58.4 \\
\hline \multirow[t]{2}{*}{ Professional Qualification } & Specialist & 37 & 36.6 \\
\hline & Consultant & 5 & 5.0 \\
\hline \multirow{2}{*}{$\begin{array}{l}\text { Basic Dental Qualification } \\
\text { (BDS or Equivalent) }\end{array}$} & Private Dental College & 55 & 54.5 \\
\hline & Government Dental College & 46 & 45.5 \\
\hline \multirow{4}{*}{$\begin{array}{l}\text { Average Monthly Income } \\
\text { (SAR) }\end{array}$} & $<10,000$ & 25 & 24.8 \\
\hline & $10,000-20,000$ & 35 & 34.7 \\
\hline & $>20,000$ & 41 & 40.6 \\
\hline & Single & 36 & 35.6 \\
\hline \multirow[t]{2}{*}{ Marital Status } & Married & 61 & 60.4 \\
\hline & Others & 4 & 4.0 \\
\hline \multirow{2}{*}{ Current Illness } & Yes & 22 & 22.0 \\
\hline & No & 78 & 78.0 \\
\hline Table & Demographic Charac & stics & \\
\hline
\end{tabular}

\begin{tabular}{|cc|}
\hline Domain & Mean \pm Standard Deviation \\
Physical Health & $57.01 \pm 18.93$ \\
Psychological & $56.11 \pm 20.81$ \\
Social Relationships & $59.68 \pm 29.69$ \\
Environment & $54.09 \pm 17.94$ \\
\hline Table 2. Quality of Life Domains (WHOQOL-100) in Dentists \\
\hline
\end{tabular}

\begin{tabular}{|c|c|c|c|c|c|}
\hline & & 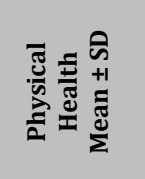 & 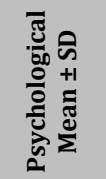 & 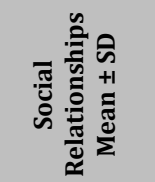 & 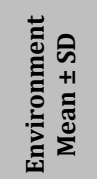 \\
\hline \multirow{3}{*}{ Gender } & Male & $\begin{array}{c}57.48 \pm \\
17.07\end{array}$ & $\begin{array}{c}58.38 \pm \\
19.38\end{array}$ & $\begin{array}{c}62.21 \pm \\
27.03\end{array}$ & $\begin{array}{c}53.73 \pm \\
17.07\end{array}$ \\
\hline & Female & $\begin{array}{c}56.42 \pm \\
21.21\end{array}$ & $\begin{array}{c}53.29 \pm \\
22.36\end{array}$ & $\begin{array}{c}56.53 \pm \\
32.74\end{array}$ & $\begin{array}{c}54.53 \pm \\
19.15\end{array}$ \\
\hline & Private & $\begin{array}{c}55.67 \pm \\
19.69\end{array}$ & $\begin{array}{c}57.00 \pm \\
23.01\end{array}$ & $\begin{array}{c}55.13 \pm \\
35.34\end{array}$ & $\begin{array}{c}53.87 \pm \\
20.85\end{array}$ \\
\hline \multirow[t]{3}{*}{ Type of Job } & Public & $\begin{array}{c}58.43 \pm \\
18.35\end{array}$ & $\begin{array}{c}55.41 \pm \\
20.44\end{array}$ & $\begin{array}{c}60.29 \pm \\
27.93\end{array}$ & $\begin{array}{c}53.95 \pm \\
16.93\end{array}$ \\
\hline & Both & $\begin{array}{c}57.67 \pm \\
18.34\end{array}$ & $\begin{array}{c}59.50 \pm \\
17.05\end{array}$ & $\begin{array}{c}72.00 \pm \\
16.02\end{array}$ & $\begin{array}{c}58.50 \pm \\
11.87\end{array}$ \\
\hline & $\begin{array}{l}\text { General } \\
\text { Dentist }\end{array}$ & $\begin{array}{c}53.93 \pm \\
19.37\end{array}$ & $\begin{array}{c}52.27 \pm \\
19.63\end{array}$ & $\begin{array}{c}53.12 \pm \\
31.60\end{array}$ & $\begin{array}{c}51.14 \pm \\
20.51\end{array}$ \\
\hline \multirow[t]{2}{*}{$\begin{array}{l}\text { Professional } \\
\text { Qualification }\end{array}$} & Specialist & $\begin{array}{c}59.27 \pm \\
17.50\end{array}$ & $\begin{array}{c}57.84 \pm \\
20.03\end{array}$ & $\begin{array}{c}65.38 \pm \\
23.42\end{array}$ & $\begin{array}{c}56.73 \pm \\
12.51\end{array}$ \\
\hline & Consultant & $76.60 \pm 9.61$ & $\begin{array}{c}88.60 \pm \\
7.60\end{array}$ & $\begin{array}{c}95.00 \pm \\
11.18\end{array}$ & $\begin{array}{c}69.40 \pm \\
7.20\end{array}$ \\
\hline \multirow{3}{*}{$\begin{array}{c}\text { Basic Dental } \\
\text { Qualification } \\
\text { (BDS or } \\
\text { Equivalent) }\end{array}$} & $\begin{array}{c}\text { Private } \\
\text { Dental } \\
\text { College }\end{array}$ & $\begin{array}{c}53.82 \pm \\
19.82\end{array}$ & $\begin{array}{c}53.69 \pm \\
24.16\end{array}$ & $\begin{array}{c}61.96 \pm \\
31.29\end{array}$ & $\begin{array}{c}55.27 \pm \\
19.25\end{array}$ \\
\hline & $\begin{array}{c}\text { Government } \\
\text { Dental } \\
\text { College }\end{array}$ & $\begin{array}{c}60.83 \pm \\
17.25\end{array}$ & $\begin{array}{c}59.00 \\
\pm 15.68\end{array}$ & $\begin{array}{c}56.96 \pm \\
27.74\end{array}$ & $\begin{array}{c}52.67 \\
\pm 16.33\end{array}$ \\
\hline & Single & $\begin{array}{l}51.19 \pm \\
22.55\end{array}$ & $\begin{array}{l}48.81 \pm \\
24.19\end{array}$ & $\begin{array}{c}48.39 \pm \\
34.10\end{array}$ & $\begin{array}{c}50.69 \pm \\
21.63\end{array}$ \\
\hline \multirow[t]{2}{*}{$\begin{array}{l}\text { Marital } \\
\text { Status }\end{array}$} & Married & $\begin{array}{c}69.50 \pm \\
19.28\end{array}$ & $\begin{array}{c}64.75 \pm \\
14.10\end{array}$ & $\begin{array}{c}59.50 \pm \\
27.89\end{array}$ & $\begin{array}{c}60.25 \pm \\
9.14\end{array}$ \\
\hline & Others & $\begin{array}{l}59.62 \pm \\
15.63\end{array}$ & $\begin{array}{c}59.85 \pm \\
17.87\end{array}$ & $\begin{array}{l}66.36 \pm \\
25.10\end{array}$ & $\begin{array}{c}55.69 \pm \\
15.72\end{array}$ \\
\hline \multirow{2}{*}{$\begin{array}{l}\text { Current } \\
\text { Illness }\end{array}$} & Yes & $\begin{array}{c}44.59 \pm \\
18.92\end{array}$ & $\begin{array}{c}51.86 \pm \\
19.68\end{array}$ & $\begin{array}{c}50.73 \pm \\
35.32\end{array}$ & $\begin{array}{c}44.73 \pm \\
20.66\end{array}$ \\
\hline & No & $\begin{array}{c}60.46 \pm \\
17.65 \\
\end{array}$ & $\begin{array}{c}57.71 \pm \\
20.89 \\
\end{array}$ & $62.49 \pm 27.7$ & $\begin{array}{c}56.82 \pm \\
16.38 \\
\end{array}$ \\
\hline
\end{tabular}

\section{Relationship between Domain Scores and Variables}

Stepwise multiple linear regression analysis was performed to assess the relationship between each of the domains and the independent variables. The only significant variable in physical or domain 1 and psychological or domain 2 was being currently ill. The variables of gender, highest qualification and currently ill were found significant in domain 3 while gender and currently ill showed a significant relationship with domain 4. (Table 4) 


\begin{tabular}{|c|c|c|c|}
\hline $\begin{array}{c}\text { Dependent } \\
\text { Variable }\end{array}$ & $\begin{array}{c}\text { Independent } \\
\text { Variable }\end{array}$ & $\begin{array}{l}\text { Regression } \\
\text { Coefficient }\end{array}$ & P-Value \\
\hline \multirow{6}{*}{ Domain 1 (Physical) } & Age & 0.28 & 0.52 \\
\hline & Gender & -0.30 & 0.45 \\
\hline & Job Type & 0.46 & 0.23 \\
\hline & Average Monthly Income & 0.46 & 0.67 \\
\hline & Highest Qualification & 0.38 & 0.74 \\
\hline & Currently Ill & 1.98 & $0.006^{*}$ \\
\hline \multirow{6}{*}{$\begin{array}{c}\text { Domain } 2 \\
\text { (Psychological) }\end{array}$} & Age & 0.21 & \\
\hline & $\begin{array}{l}\text { Age } \\
\text { Gender }\end{array}$ & -0.18 & 0.70 \\
\hline & Job Type & 0.36 & 0.55 \\
\hline & Average Monthly Income & 0.72 & $\begin{array}{l}0.55 \\
0.26\end{array}$ \\
\hline & Highest Qualification & & 0.67 \\
\hline & Currently Ill & $\begin{array}{l}0.54 \\
1.86\end{array}$ & $0.004^{*}$ \\
\hline \multirow{6}{*}{$\begin{array}{l}\text { Domain } 3 \text { (Social } \\
\text { Relationship) }\end{array}$} & Age & 0.29 & 0.49 \\
\hline & Gender & -0.17 & $0.02^{*}$ \\
\hline & Job Type & -0.34 & 0.64 \\
\hline & Average Monthly Income & -0.79 & 0.18 \\
\hline & Highest Qualification & 0.28 & $0.01^{*}$ \\
\hline & Currently Ill & 1.21 & $0.02^{*}$ \\
\hline \multirow{6}{*}{$\begin{array}{c}\text { Domain } 4 \\
\text { (Environmental) }\end{array}$} & Age & 0.12 & 0.22 \\
\hline & Gender & 0.55 & $0.01^{*}$ \\
\hline & Job Type & 0.82 & 0.20 \\
\hline & Average Monthly Income & -0.24 & 0.86 \\
\hline & Highest Qualification & -0.98 & 0.25 \\
\hline & Currently Ill & 0.10 & $0.003 *$ \\
\hline
\end{tabular}
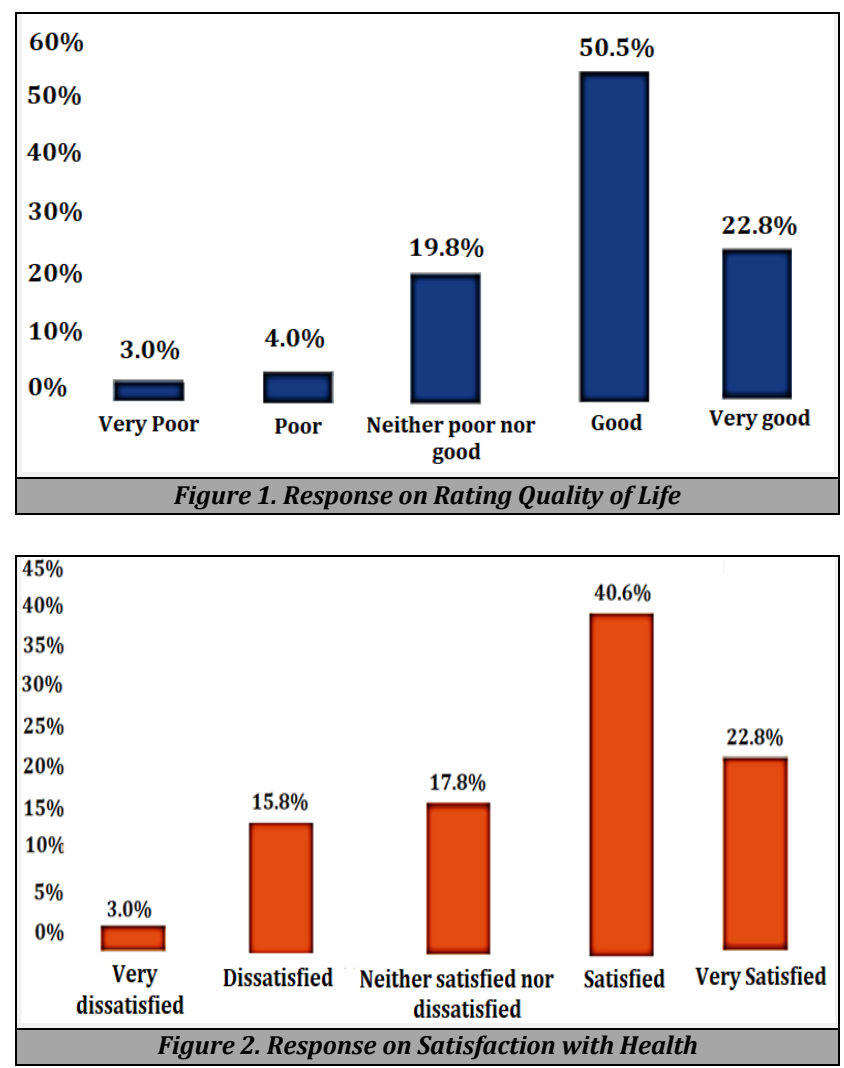

Quality of Life Domains (WHOQOL-100) in Dentists by Demographic Characteristics

Table 3 shows the mean transformed score on a scale of 0 - 100 and standard deviation of each domain by demographic characteristics. Male scored highest in all domains except environment. No statistically significant differences were observed in all the four QOL domains according to gender $(\mathrm{p}>$ 0.05). Respondents who are married scored highest in all domains except social relationships ( $p>0.05)$.

Respondents working in both public and private job scored highest in all the domains except physical health ( $p>.05)$. Respondents with basic dental qualification (BDS or equivalent) from government dental colleges scored highest in physical health and psychological than those from private dental colleges ( $p>0.05$ ). Consultants had better QOL in all the domains. There was statistically significant difference in all the domains $(\mathrm{p}<0.05)$ except environment $(\mathrm{p}>0.05)$. Consultants scored statistically significantly higher score than general dentists in physical health, psychological, and social relationships $(\mathrm{p}<0.05)$. In addition, consultants scored statistically significantly higher score than specialists in psychological $(\mathrm{p}<0.05)$.

There was a positive correlation between age and all the domain scores. Statistically significant correlation was found only between age and physical health $(\mathrm{p}<0.05)$. There was a statistically significant negative correlation between year of graduation and all the domain scores $(p<0.05)$ except environment $(p>0.05)$. Statistically significant positive correlation was found between average monthly income (SAR) and all the domain scores $(\mathrm{p}<0.05)$ except environment $(\mathrm{p}>$ 0.05). Respondents without any current illness had better QOL in all the domains. Moreover, statistical significance was found in physical health and environment $(\mathrm{p}<0.05)$.

\section{DISCUSSION}

Work-related stress and the psychosocial risk is not only an imperative question, but also moral. ${ }^{9}$ QOL assessments are essential since productivity of any work is directly related to job satisfaction and QOL thereof. Unlike their counterpart in the health care professionals like physicians, dental health care professionals are combination of technical and medical individuals, who need to understand the physiological system of the body (as physicians) as well as to know the technical aspect of the materials and methods (as engineers) employed in their field. ${ }^{10}$ This required quality to imbibe and practice and maintaining the standard of practice is not an easy task. ${ }^{11,12}$

Constantly updating the required skills in rapidly growing field of dentistry, competition from the colleague in the next door practice, physical fitness to fulfil the ergonomics of the dentistry, role to play as an entrepreneur, above all economics to keep at a bay can make any dentist burnout and overworked which may have impact on the QOL. In any profession, burnout affects all aspects of life including marital problems, social life, emotional disorders, and problems with alcohol and drug abuse. Dentist is not an exception to this.

Previous studies in medical field clearly show that this burnout has a devastating effect on the patients, resulting in medical errors and reduced compliance to medical advice. ${ }^{13-}$ 15 Dentists work environment is different from that of a medical field in many ways and dentist is expected to face many more challenges and stress burst. Stress and job satisfaction have a complex interrelation and exposure to stress, expected dentists' job to affect negatively. ${ }^{16}$ Considering all these aspects, the present study conducted is very much in need to understand the dentist's life at a glance and to plan better the life of present and future dentists.

Instrument and method employed the WHO for QOL Assessment-BREF (WHOQOL-BREF) in the present study is well known and well tested not only in medical and dental field but also in other jobs. To meet the local cultural requirements, modifications done are not expected to change the overall assessment and easily allow the comparison to be done with the other previous studies. 
The number of respondents in the present study is very well above the response rate of some of the previous studies $^{5,17}$ and below the level of study by Doshi et al. ${ }^{18}$ The better response obtained in the present study may be related to multiple choices given to fill the questionnaire. The lower response seen compare to the study of Doshi et al. could be because, in their study, it was conducted among the faculty of dental schools, where the accessibility is better than the dentists working in dental clinics. Male and female respondents of the present study were comparatively equal and can be easily compared and thus gender comparison to the entire domain is easier and acceptable.

The majority of the respondents expressed their quality of life as good or very good which is a positive sign. It is also to be noted that, though the males scored higher in all the domains, there was no statistical significance difference between males and females. This shows that dentists' professional life is irrespective of gender which is a "welcome" sign.

As it is seen with all the available studies till today done to assess the quality of dentist life, the highest mean score is obtained with the social domain in the present study. Social domain largely reflects the combination of communication strength of a dentist, relation with the influential people in the society, and the marital status. To prove this fact, present study showed that QOL of married dentists was better than the single dentist. These results are consistent with the findings of previous studies.5,16,19

Being married than single may be the reason for the better status seen among the married dentists due to increased opportunity to share with the loved ones, home environment management by other members of the family, and better scope for get together with relatives and other family members. Moreover, single dentists are younger than the married dentists, so the life experience and lessons learnt to tackle the life events are better handled by a married than the single person. Present study thus also showed positive correlation between age and all the domains suggesting that life events teaches many lessons and exposes a dentist as age advances and puts him / her in a better position to handle the given situation.

Consultants are highly qualified and require doing the work totally dedicated to their selected field. Though they handle the cases referred by the general dentists and specialists, which itself explains that they get to work with some of the difficult cases which cannot be handled by their fellow junior colleagues in the field. Expertise they have in their field and working in comparatively narrow field of dental work make them masters in their work, which is often expected to make their QOL better than the general dentist workload. 'Present study results in this aspect are similar to the past studies. 5,14

Further it is to be noted that, consultants are possibly having improved financial status due to their increase number of years in practice, thus feel more secure with their life including health and social care. This is expected to increase time and resources to spend for recreation / leisure activities and acquire new information and skills which in turn could affect their confidence to handle any given case and reduce the stress thereof. Poor satisfaction in general dentist may be related due to their new entry in the dental practice, competition among the fellow dentists, fear about career goals and less opportunity to improve the skills by themselves. ${ }^{20,21}$
In the present study, the results revealed that the dentists working both in private and public enjoys better QOL than the dentists working in public or private alone. The results should be viewed cautiously, since the number of subjects working both in public and private are comparatively low. Nevertheless, studies done in other job sectors always proved that, public sector workers enjoy better quality of life than private sector. ${ }^{22}$ Job security and steady income may be the factors associated with public sector which relieves partially the financial stress they need to face than solely being in the private practice may be the reason for the better QOL seen among dentists working both for private and public sector. ${ }^{23,24}$

Though the study reported a similar trend to the previous studies, there are certain limitations in the present study. Study concentrated at general in dentists who included all the groups of dental community including general dentist, specialist, and consultants. To better view the QOL, study may be conducted solely for the general dental practitioners or dental specialist. Number of sample size may though appear to be adequate, further research need to be conducted with increased sample size. A better comparison of dentists only in academic environment compared to clinical practice alone may further open up the field to get more information and knowledge may be widened.

\section{CONCLUSIONS}

Within the limitations of the study, it can be concluded that most of the participated dentists experienced good quality of life irrespective of gender and work grades.

Data sharing statement provided by the authors is available with the full text of this article at jemds.com.

Financial or other competing interests: None.

Disclosure forms provided by the authors are available with the full text of this article at jemds.com.

\section{REFERENCES}

[1] Minayo MCS, Hartz ZMA, Buss PM. Quality of life and health: a necessary debate. Ciência \& Saúde Coletiva. 2000;5(1):7-18.

[2] Puriene A, Aleksejuniene J, Petrauskiene J, et al. Occupational hazards of dental profession to psychological wellbeing. Stomatologija 2007;9(3):72-8.

[3] Baiju R, Peter E, Varghese N, et al. Oral health and quality of life: current concepts. J Cin Diagn Res 2017;11(6):ZE21.

[4] Andre A, Pierre GC, McAndrew M. Quality of life among dental students: a survey study. J Dent Educ 2017;81(10):1164-70.

[5] Abraham SB, Amini AMA, Khorshed NE, et al. Quality of life of dentists. Eur J Dent 2018;12(1):111-5.

[6] Logan H, Muller PJ, Berst MR, et al. Contributors to dentists' job satisfaction and quality of life. J Am Coll Dent 1997;64(4):39-43.

[7] Shugars DA, DiMatteo M, Hays R, et al. Professional satisfaction among california general dentists. J Dent Educ 1990;54(11):661-9. 
[8] Development of the World Health Organization WHOQOL-bref quality of life assessment. The WHOQOL group. Psychol Med 1998;28(3):551-8.

[9] Mosadeghrad AM, Ferlie E, Rosenberg D. A study of relationship between job stress, quality of working life and turnover intention among hospital employees. Health Serv Manage Res 2011;24(4):170-81.

[10] Sehlen S, Vordermark D, Schäfer C, et al. Job stress and job satisfaction of physicians, radiographers, nurses and physicists working in radiotherapy: a multicenter analysis by the DEGRO quality of life work group. Radiat Oncol 2009;4:6.

[11] Guler N, Kuzu F. The health-related quality of life of the health professionals working in the primary healthcare centers and its correlation with selected sociodemographic factors in sivas, a central Anatolian city. Sci Res Essays 2009;4(12):1547-52.

[12] Kheiraoui F, Gualano MR, Mannocci A, et al. Quality of life among healthcare workers: a multicentre cross-sectional study in Italy. Public Health 2012;126(7):624-9.

[13] De Valk M, Oostrom C. Burnout in the medical professioncauses, consequences and solutions. Occup Health Work 2007;3:1-5.

[14] Gorter RC, Freeman R. Burnout and engagement in relation with job demands and resources among dental staff in northern ireland. Community Dent Oral Epidemiol 2011;39(1):87-95.

[15] Norlund S, Reuterwall C, Höög J, et al. Burnout, working conditions and gender--results from the northern Sweden MONICA study. BMC Public Health 2010;10:326.
[16] Rada RE, Johnson-Leong C. Stress, burnout, anxiety and depression among dentists. J Am Dent Assoc 2004;135(6):788-94.

[17] Nunes MF, Freire MCM, Leles CR. Quality of life of public health service dental hygienists in Goiania, Brazil. Int J Dent Hyg 2008;6(1):19-24.

[18] Doshi D, Jain A, Vinaya K, et al. Quality of life among dentists in teaching hospitals in South Canara, India. Indian J Dent Res 2011;22(4):552-5.

[19] Wig N, Lekshmi R, Pal H, et al. The impact of HIV/AIDS on the quality of life: a cross sectional study in north India. Indian J Med Sci 2006;60(1):3-12.

[20] Jeong SH, Chung JK, Choi YH, et al. Factors related to job satisfaction among south Korean dentists. Community Dent Oral Epidemiol 2006;34(6):460-6.

[21] Yildiz S, Dogan B. Self reported dental health attitudes and behaviour of dental students in Turkey. Eur J Dent 2011;5(03):253-9.

[22] Uzaina. Psychological well-being and quality of life among public and private sector employee. The International Journal of Indian Psychology 2019;7(2):946-50.

[23] Kumar A, Bhat PS, Ryali S. Study of quality of life among health workers and psychosocial factors influencing it. Ind Psychiatry J 2018;27(1):96-102.

[24] Zeinabadi MS, Safaian G, Mirmohammadkhani 0, et al. Evaluation of health-related quality of life among dentists in Semnan, Iran, 2015-2016. Middle East J Rehabil Health Study 2018;5(4):e83626. 